\title{
Brine shrimp bioassay of some species of Solanum from Northestern Brazil
}

\author{
Tania Maria S. Silva ${ }^{1 *}$, Roberto Jefferson B. Nascimento ${ }^{2}$, Michelle M. Batista ${ }^{2}$, \\ Maria F. Agra', Celso A. Camara ${ }^{3}$
}

\author{
${ }^{1}$ Núcleo Complexo Produtivo de Saúde, Instituto Multidisciplinar em Saúde, Campus Avançado Anísio Teixeira, \\ Avenida Olívia Flores, 3000, Candeias, 45055-090, Vitória da Conquista, BA, Brazil, \\ ${ }^{2}$ Laboratório de Tecnologia Farmacêutica, Universidade Federal da Paraíba, Caixa Postal 5009, 58051-970, \\ João Pessoa, PB, Brazil, \\ ${ }^{3}$ Departamento de Química, Universidade Federal Rural de Pernambuco, R. Dom Manoel de Medeiros, $s / n$, \\ Dois Irmãos, 52171-900, Recife, PE, Brazil
}

\begin{abstract}
RESUMO: "Bioatividade em Artemia salina de várias espécies de Solanum do Nordeste Brasileiro". Os extratos metanólicos de 13 espécies de Solanum (Solanaceae) foram testados para verifificação da bioatividade em Artemia salina. As espécies testadas (partes aéreas, raízes e frutos) foram: S. asperum, S. capsicoides, S. palinacantum, S. paludosum, S. paniculatum, S. paraibanum, S. sisymbriifolium, $S$. crinitum, $S$. diamantinense, $S$. megalonyx, $S$. torvum, $S$. asterophorum e $S$. stipulaceum. Das treze espécies testadas, quatro foram inativas. Os extratos dos frutos de $S$. asperum $\left(\mathrm{CL}_{50}=420,5 \mu \mathrm{g} / \mathrm{mL}\right)$ e $S$. paludosum $\left(\mathrm{CL}_{50}=548,0 \mu \mathrm{g} / \mathrm{mL}\right)$, partes aéreas de $S$. diamantinense $\left(\mathrm{CL}_{50}=481,0 \mu \mathrm{g} / \mathrm{mL}\right)$ e $S$. sisymbrifolium $\left(\mathrm{CL}_{50}=382,7 \mu \mathrm{g} / \mathrm{mL}\right)$, e das raízes $S$. asperum $\left(\mathrm{CL}_{50}=\right.$ $593,4 \mu \mathrm{g} / \mathrm{mL})$ e $S$. stipulaceum $\left(\mathrm{CL}_{50}=823,1 \mu \mathrm{g} / \mathrm{mL}\right)$ que mostraram atividade moluscicida contra Biomphalaria glabrata também mostraram atividade tóxica em Artemia salina.
\end{abstract}

Unitermos: Solanaceae, Solanum, Artemia salina, bioatividade.

\begin{abstract}
The methanolic extracts of 13 Specieis of the genus Solanum (Solanaceae) have been tested for bioactivity in Artemia salina. The extracts investigated were prepared from various parts (aerial parts, roots and fruits) of S. asperum, S. capsicoides, $S$. palinacantum, $S$. paludosum, S. paniculatum, S. paraibanum, S. sisymbriifolium, S. crinitum, $S$. diamantinense, S. megalonyx, $S$. torvum, S. asterophorum and S. stipulaceum. The lethal concentrations were determined for the extracts and among thirteen plants tested, four appear to be inactive. The extracts of the fruits of $S$. asperum $\left(\mathrm{LC}_{50}=420.5 \mu \mathrm{g} / \mathrm{mL}\right)$ and $S$. paludosum $\left(\mathrm{LC}_{50}=548.0 \mu \mathrm{g} / \mathrm{mL}\right)$, aerial parts of $S$. diamantinense $\left(\mathrm{LC}_{50}=481.0 \mu \mathrm{g} / \mathrm{mL}\right)$ and S. sisymbrifolium $\left(\mathrm{LC}_{50}=382.7 \mu \mathrm{g} / \mathrm{mL}\right)$, and the roots of S. asperum $\left(\mathrm{LC}_{50}=593.4 \mu \mathrm{g} / \mathrm{mL}\right)$ and S. stipulaceum $\left(\mathrm{LC}_{50}=823.1 \mu \mathrm{g} / \mathrm{mL}\right)$, all of which previously showed molluscicidal activity against Biomphalaria glabrata were also found to be active in the present study with brine shrimp.
\end{abstract}

Keywords: Solanaceae, Solanum, Artemia salina, bioactivity, brine shrimp.

\section{INTRODUCTION}

The genus Solanum is considered to be one of the largest and most complex among the Angiosperms. It is comprised of about 1500 species and has at least 5000 published epithets (Nee, 1999). The genus is well represented in Brazil and is widely distributed from north to south in diverse phytogeographic regions. Many of the species are endemic to the country and well represented in the northeast Brazil with about 80 species which are widely distributed in the region. About 20 of these Solanum species are endemic to the northeastern region (Agra, 1999) and are widely used in folk medicine, commonly known as "jurubeba"; the name derived from the Tupi-guarani word "yu'beba", which refers to the presence of prickles in some of them.

The presence of the steroidal alkaloid solasodine, which is potentially an important starting material for the synthesis of steroid hormones, is characteristic of the genus Solanum (Silva et al., 2005a; Silva et al., 2005b; Barbosa-Filho et al., 1991).

The brine shrimp assay has been established as a safe, practical, and economic method for the determination of the bioactivity of synthetic compounds (Almeida et al., 2002) as well as plant products (Meyer et al., 1982; McLaughlin et al., 1991; Lhullier et al., 2006; Stefanello et al., 2006). The significant correlation between the brine shrimp assay and in vitro growth inhibition of human solid tumor cell lines demonstrated by the National Cancer Institute (NCI, USA) is significant because it 
shows the value of this bioassay as a pre-screening tool for antitumor drug research (Anderson et al., 1991). The wide distribution, anticancer properties (Kupchan et al., 1965; Cham et al., 1987; Cham, 1994; Daunter; Cham, 1990; Hu et al., 1999; Esteves-Souza et al., 2002; Lee et al., 2004; Friedman et al., 2005) of the glycoalkaloids and molluscicidal activity (Silva et al., 2005c) of the crude extracts, led us to the selection of these Solanum species for the present work.

\section{MATERIAL AND METHODS}

\section{Plant material}

All together, 13 species of the genus Solanum were investigated in our present study. All species were collected in Northeastern Brazil and identified by M. F. Agra, the Head of the Botany Section of LTF-UFPB. Voucher specimens (Table 1) were deposited at the Prof. Lauro Pires Xavier Herbarium (JPB) and the duplicates were kept in the collection of references at LTF, both at the Universidade Federal da Paraíba, João Pessoa, Brazil.

\section{Preparation of the crude extract}

The extracts for the present study for bioassay against Artemia salina were prepared as follows: The dried and powdered plant materials such as, fruits of $S$. asperum, S. capsicoides, $S$. palinacantum, S. paludosum, $S$. paniculatum, $S$. paraibanum and $S$. sisymbriffolium, aerial parts of $S$. asperum, $S$. asterophorum, $S$. capsicoides, S. crinitum, S. diamantinense, S. megalonyx, $S$. palinacantum, $S$. paniculatum, $S$. sisymbrifolium, and $S$. torvum, and roots of $S$. asperum, $S$. asterophorum, $S$. palinacantum, $S$. paludosum and $S$. stipulaceum were extracted with methanol at room temperature followed by treatment as described before (Silva et al., 2005c) for the preparation of the test samples for molluscicidal activity.

\section{Biological assay}

The brine shrimp lethality assay was performed following the reported procedure (Meyer, 1982) with some modifications (Silva et al, 2005d). The growth medium was prepared with sea water in a small tank divided into two compartments. The shrimp eggs were added to the covered compartment. A lamp was placed above the open side of the tank to attract hatched shrimps through perforations in the partition wall. After $48 \mathrm{~h}$, the shrimps mature as nauplii (A. salina) and are ready for the assay. Test extracts were dissolved in three drops of Cremophor $^{\circledR}, 2 \mathrm{~mL}$ of DMSO and sea water to complete 5 $\mathrm{mL}$ of total volume. Appropriate volumes of the resulting solution were then added in tubes, in quadruplicate, with $5 \mathrm{~mL}$ of saline solution containing 10 nauplii each to afford the final sample concentrations. The control samples containing Cremophor ${ }^{\circledR}$ and DMSO, under the same conditions, do not cause significant brine shrimp mortality. After $24 \mathrm{~h}$ incubation under light, the number of dead and survivor brine shrimps in each tube was counted. The $\mathrm{LC}_{50}$ values were calculated by graphics from drug concentration vs. lethality percentage using a probit scale adjust. Data analysis was performed with Origin 6.0 software.

\section{RESULTS AND DISCUSSION}

Many of the collected species for the present study are already used in folk medicine. The roots of S. asterophorum, S. paniculatum and S. torvum, for example, are used in the treatment of liver diseases (Agra; Bhattacharrya, 1999), and this appears to be its most common ethnomedicinal use. A wine is produced commercially from the fruits of $S$. paniculatum, which also have use in popular medicine. Solanum asperum can cause skin irritation (Agra; Battacharyya, 1999). The ethnomedicinal data and other uses of the studied Solanum species are given in Table 1 . The plants known to be toxic in popular medicine also showed brine shrimp bioactivity in our study.

The brine shrimp lethality for different extracts of Solanum species are given in Table 2. The extracts are considered inactive when all nauplii survive at a concentration of $1000 \mu \mathrm{g} / \mathrm{mL}$ (Meyer 1982). Among the thirteen plants tested, four seems to be inactive. As stated in Table 2, the extracts demonstrating molluscicidal activity (Silva et al., 2005c) were also found to be active in the brine shrimp assay. The aerial parts of $S$. asperum (entry 1) and S. megalonyx (entry 10), and the roots of $S$. palinacanthum (entry 13) were found to be inactive in both molluscicidal and brine shrimp bioassays.

The data in Table 2 show that many Solanum species (S. asterophorum, S. capsicoides, S. crinitum, $S$. palinacanthum, $S$. paniculatum, $S$. sisymbrifolium, and $S$. torvum) which are active in brine shrimp bioassay are not active against the mollusk Biomphalaria glabrata. On the other hand, all the Solanum species which demonstrated molluscicidal activity (Silva et al., 2005c) were also active against $A$. salina. The most active extracts in this study were found to be the ones from the roots of $S$. asterophorum $\left(\mathrm{CL}_{50}=107.3 \mu \mathrm{g} / \mathrm{mL}\right.$; entry 5) and from the aerial parts of $S$. torvum with $\mathrm{CL}_{50}=295.2 \mu \mathrm{g} / \mathrm{mL}$ (entry 22). Surprisingly, the chemical study of the latter species did not show the presence of any glycoalkaloid (Mahmood et al., 1985), whereas, the former showed the presence of alkaloids (Silva et al., 2005c). This suggests that the observed bioactivity is not only due to the presence of alkaloids but other constituents (e.g., saponins, sapogenins) may also play an important role.

The molluscicidal activity seen in some Solanum species is generally attributed to the presence of glycoalkaloids. The other classes of secondary metabolites, including alkamines, have little if any activity (Alzerreca; Hart, 1982; Wanyonyi et al., 2003; 
Table 1. Ethnomedicinal and other uses of Solanum species in the Northeast Brazil. $\mathrm{R}=$ Roots; $\mathrm{L}=\mathrm{Leaves} ; \mathrm{F}=$

\begin{tabular}{|c|c|c|c|}
\hline Plant name & Common name & $\begin{array}{l}\text { Voucher } \\
\text { Agra }^{\circ}\end{array}$ & $\begin{array}{l}\text { Medicinal use } \\
\text { (Part used) }\end{array}$ \\
\hline S. asperum Rich. & Jussara & 1243 & Skin irritant (L) \\
\hline S. asterophorum Mart. & Jurubeba-de-fogo & 1744 & In liver diseases \\
\hline S. capsicoides All. & Gogoia & 1292 & Toxic $(F)$ \\
\hline S. crinitum Lam. & Jurubeba & 2246 & Toxic $(\mathrm{F})$ \\
\hline S. diamantinense & Jurubeba & 5176 & Unknown \\
\hline S. megalonyx Sendtn. & Jurubeba & 5987 & Unknown \\
\hline S. palinacanthum Dunal & Jurubeba & 1296 & Toxic $(F)$ \\
\hline S. paludosum Moric. & Jurubeba-roxa & 1100 & Toxic $(F)$ \\
\hline S. paniculatum L. & Jurubeba & 1261 & $\begin{array}{l}\text { Anemia. Tuberculosis, } \\
\text { liver diseases }(\mathrm{L}, \mathrm{R})\end{array}$ \\
\hline S. paraibanum Agra & Jurubeba-de-rama & 1111 & Unknown \\
\hline S. sisymbrifolium Lam. & Jurubeba & 5553 & Unknown \\
\hline S. stipulaceum Roem. \& Schult. & Jurubeba-roxa & 1806 & Toxic (F) \\
\hline S. torvum $\mathrm{Sw}$. & Jurubeba & 1477 & In liver diseases \\
\hline
\end{tabular}

Table 2. Median lethal concentrations of methanolic extracts of Solanum species of the roots, aerial parts and/or fruits against brine shrimp assay $(\mathrm{AP}=$ Aerial Parts; $\mathrm{F}=$ Fruits; $\mathrm{R}=$ Roots $)$

\begin{tabular}{|c|c|c|c|c|}
\hline Entry & Plant name & Part tested & $\begin{array}{l}\text { Brine shrimp } \\
\text { Assay }\left(\mathrm{CL}_{50}\right)^{\mathrm{a}}\end{array}$ & $\begin{array}{l}\text { Molluscicidal } \\
\text { activity }\left(\mathrm{CL}_{90}\right)\end{array}$ \\
\hline 1 & S. asperum Rich. & AP & $>1000$ & Inactive \\
\hline 2 & & $\mathrm{~F}$ & 420.5 & Active (43.56) \\
\hline 3 & & $\mathrm{R}$ & 593.4 & Active (44.11) \\
\hline 4 & S. asterophorum Mart. & AP & 552.8 & Inactive \\
\hline 5 & & $\mathrm{R}$ & 107.3 & Inactive \\
\hline 6 & S. capsicoides All. & AP & 440.1 & Inactive \\
\hline 7 & & $\mathrm{~F}$ & 476.9 & Inactive \\
\hline 8 & S. crinitum Lam. & AP & 833.4 & Inactive \\
\hline 9 & S. diamantinense & $\mathrm{AP}$ & 481.0 & Active (52.80) \\
\hline 10 & S. megalonyx Sendtn. & AP & $>1000$ & Inactive \\
\hline 11 & S. palinacanthum Dunal & $\mathrm{AP}$ & 488.3 & Inactive \\
\hline 12 & & $\mathrm{~F}$ & $>1000$ & Inactive \\
\hline 13 & & $\mathrm{R}$ & $>1000$ & Inactive \\
\hline 14 & S. paludosum Moric. & $\mathrm{F}$ & 548.0 & Active (82.86) \\
\hline 15 & & $\mathrm{R}$ & $>1000$ & Inactive \\
\hline 16 & S. paniculatum L. & $\mathrm{AP}$ & 953.9 & Inactive \\
\hline 17 & & $\mathrm{~F}$ & 823.2 & Inactive \\
\hline 18 & S. paraibanum Agra & $\mathrm{F}$ & 694.8 & Inactive \\
\hline 19 & S. sisymbrifolium Lam. & $\mathrm{AP}$ & 382.7 & Active (46.66) \\
\hline 20 & & $\mathrm{~F}$ & 696.4 & Inactive \\
\hline 21 & S. stipulaceum Roem. \& Schult. & $\mathrm{R}$ & 823.1 & Active (73.87) \\
\hline 22 & S. torvum Sw. & AP & 295.2 & Inactive \\
\hline
\end{tabular}

a. $\mathrm{CL}_{50}>1000 \mu \mathrm{g} / \mathrm{mL}$ is inactive; b. Silva et al., $2005 \mathrm{c}$

Silva et al., 2005c). Our study, however, showing bioactivity in the brine shrimp assay for some extracts with no corresponding molluscicidal activity suggests that other classes of secondary metabolites must be involved in the process, and, therefore, other screening (e.g., anticancer, antifungical) must be performed on such extracts.

\section{ACKNOWLEDGEMENTS}

The authors thank CNPq, CAPES, IMSEAR$\mathrm{CNPq}$, and PIBIC-UFPb for scholarships and financial support, and Prof. J. Bhattacharyya from Laboratório de Tecnologia Farmacêutica-UFPB for useful help in the preparation of the manuscript.

\section{REFERENCES}

Agra MF 1999. Diversity and distribution of Solanum subgenus Leptostemonum in North-East Brazil. In Nee M, Symon DE, Lester RN \& Jessop JP (editors). Solanaceae IV, 
Royal Botanic Gardens, Kew, pp. 197-203.

Agra MF, Bhattacharyya J 1999. Ethnomedicinal and phytochemical investigation of Solanum species in Northeast of Brazil. In Nee M, Symon DE Lester RN \& Jessop JP (editors). Solanaceae IV, Royal Botanic Gardens, Kew, pp. 341-343.

Almeida PA, Silva TMS, Echevarria A 2002. Mesoionic 5-alkyl1,3-dithiolium-4-thiolates: Synthesis and brine shrimp toxicity. Heterocycl Comm 8: 593-600.

Alzerreca A, Hart G 1982. Molluscicidal steroid glycoalkaloids possessing stereoisomeric spirosolane structures. Toxicol Lett 12: 151-155.

Anderson JE, Goetz CM, McLaughlin JL, Suffness M 1991. A blind comparison of simple bench-top bioassay and human tumour cell cytotoxicities as antitumor prescreens. Phytochem Analysis 2: 107-111.

Barbosa-Filho JM, Agra MF, Oliveira RAG, Paulo MQ, Troling G, Cunha EVL, Ataide JR, Bhattacharyya J 1991. Chemical and pharmacological investigation of Solanum species of Brazil - a search for solasodine and other potentially useful therapeutic agents. Mem I Oswaldo Cruz 86: 189-191.

Cham BE 1994. Solasodine glycosides as anti-cancer agents: preclinical and clinical studies. Asian Pac J Pharmacol 9: 113-118.

Cham BE, Gilliver M, Wilson L 1987. Antitumor effects of glycoalkaloids isolated from Solanum sodomaeum. Planta Med 53: 34-36.

Daunter B, Cham BE 1990. Solasodine glycosides. In vitro preferential toxicity for human cancer cells. Cancer Lett 55: 209-220.

Esteves-Souza A, Silva TMS, Alves CCF, de Carvalho MG, Braz-Filho R, Echevarria A 2002. Cytotoxic activities against Ehrlich carcinoma and human K562 leukemia of alkaloids and flavonoid from two Solanum species. J Braz Chem Soc 13: 838-842.

Friedman M, Lee KR, Kim HJ, Lee IS, Kozukue N 2005. Anticarcinogenic effects of glycoalkaloids from potatoes against human cervical, liver, lymphoma, and stomach cancer cells. J Agric Food Chem 53: 61626169.

Hu K, Kobyashi H, Dong A, Jing Y, Iwasaki S, Yao X 1999. Antineoplastic agents III: steroidal glycosides from Solanum nigrum. Planta Med 65: 35-38.

Kupchan SM, Barboutis SJ, Knox JR, Lau Cam CA 1965. $\alpha-$ Solamarine tumor inhibitor isolated from Solanum dulcamara. Science 150: 1827-1829.

Lee KR, Kozukue N, Han JS, Park JH, Chang EY, Baek EJ, Chang JS, Friedman M 2004. Glycoalkaloids and metabolites inhibit the growth of human colon (HT29) and liver (HepG2) cancer cells. J Agric Food Chem 52: 2832-2839.

Lhullier C, Horta PA, Falkenberg M 2006. Avaliação de extratos de macroalgas bênticas do litoral catarinense utilizando o teste de letalidade para Artemia salina. Rev Bras Farmacogn 16: 158-163.

Mahmood U, Agrawal PK, Thakur RS 1985. Torvonin-A, a spirostane saponin from Solanum torvum leaves. Phytochemistry 24: 2456-2457.

McLaughlin JL, Chang CJ, Smith DL 1991. "Bench-top" bioassays for the discovery of bioactive natural products: an update. In: Rahman A, ed., Studies in Natural Product Chemistry 9, Elsevier, Amsterdam, pp. 383-409.

Meyer BN, Ferrigni NR, Putnam JE, Jacobsen LB, Nichols DE, McLaughlin JL 1982. Brine shrimp: A convenient general bioassay for active plant constituents. Planta Med 45: 31-34.

Nee M 1999. Synopsis of Solanum in the New World. In: Nee, M., Symon DE, Lester RN \& Jessop JP Solanaceae IV: advances in biology and utilization. Royal Botanic Gardens, Kew, pp.285-333.

Silva TMS, Costa RA, Oliveira EJ, Barbosa-Filho JM, Agra MF, Camara CA 2005a Complete $1 \mathrm{H}$ and $13 \mathrm{C}$ NMR assignments of isojuripidine from Solanum asterophorum Mart. J Braz Chem Soc 16(6B): 14671471.

Silva TMS, Agra MF, Bhattacharyya J 2005b Studies on the alkaloids of Solanum of northeastern Brazil. Rev Bras Farmacogn 15: 292-293.

Silva TMS, Batista MM, Camara CA, Agra MF 2005c. Molluscicidal activity of some Brazilian Solanum spp. (Solanaceae) against Biomphalaria glabrata. Ann Trop Med Parasitol 99: 419-425.

Silva TMS, Camara CA, Barbosa TP, Soares AZ, Cunha LC, Pinto AC, Vargas MD 2005d. Molluscicidal activity of synthetic lapachol amino and hydrogenated derivatives. Bioorg Med Chem 13: 193-196.

Stefanello MEA, Salvador MJ, Ito IY, Macari PAT 2006. Avaliação da atividade antimicrobiana e citotóxica de extratos de Gochnatia polymorpha ssp. floccosa. Rev Bras Farmacogn 16: 525-530.

Wanyonyi AW, Chhabra SC, Mkoji G, Njue W, Tarus PK 2003. Molluscicidal and antimicrobial activity of Solanum aculeastrum. Fitoterapia 74: 298-301. 